\title{
Teaching Equals Helping Students Learn
}

\author{
Joseph F. O'Donnell
}

Published online: 22 March 2013

(C) Springer Science+Business Media New York 2013

I had the occasion this week to reflect on teaching and it brought me back to something I remember Steve Abrahamson, Phd, $\mathrm{ScD}$, one of the giants of medical education from the University of Southern California Keck School of Medicine said at one of the Asssociation of American Medical Colleges meeting years ago. He read the dictionary definition of teaching and said to the audience "now there's the problem. "I looked up the definition again: here it is (from the Merriam Webster Unabridged Dictionary): To teach

$1 \mathrm{a}:$ to cause to know something <taught them a trade>

b : to cause to know how $<$ is teaching me to drive $>$

c : to accustom to some action or attitude $<$ teach students to think for themselves>

d : to cause to know the disagreeable consequences of some action $<$ I'll teach you to come home late $>$

2: to guide the studies of

3: to impart the knowledge of <teach algebra $>$

$4 \mathrm{a}:$ to instruct by precept, example, or experience

$\mathrm{b}$ : to make known and accepted <experience teaches us our limitations $>$

5: to conduct instruction regularly in

Steve advocated for this definition and I wholeheartedly agree with it: TO TEACH IS TO HELP A STUDENT TO LEARN. Now, that definition may be caught somewhere in the causing or imparting or instructing above and maybe best in the guiding, but that dictionary definition just doesn't do it for me as much as Steve's simpler concept. To me, it puts the focus in the right place...on the learner.

Recently, I was honored to be asked to do a short speech at the graduation ceremony for Franklin Pierce University's

J. F. O’Donnell ( $\bowtie)$

Geisel School of Medicine at Dartmouth,

Hanover, NH 03755, USA

e-mail: Joseph.F.ODonnell@dartmouth.edu
Physician Assistant students. In preparing for it, I did a little homework about PA's. Money Magazine declared that in 2008, this was the 5th best job in America-growing rapidly in both stature and responsibility. In preparation. I learned that Dr Eugene Stead was the founder of the first PA program at Duke. Dr Stead was the mentor of a former dean at my school and I had the honor him at the dean's retirement ceremony at the age of 90 . He was sharp as a tack and one of the most inspiring teachers I ever met. There are a whole bunch of his quotes-they are called "Stead-isms"-not unlike "Osler-isms" or "Peabody-isms" ("The secret of the care of the patient is to care for the patient"). Dr Stead regarded people as the primary product of an educational institution, and his highest priority as a teacher was to help people learn: learn about medicine, learn about how to learn, learn about themselves, and learn about others. Anyhowhere's a set of quotes (about learning!) from Dr Stead that I always remembered:

"In any educational institution the primary product is molded and trained men [and women]. A person capable of reading books written in many different languages, a person experienced in the manipulation of ideas, a person capable of using this background for the identification and solution of now-solvable problems; these are the most important results of an educational system. I always focused on learners and learning rather than teaching. I cannot teach you anything, I can only provide a setting in which you can learn. I don't lecture, I focus on attitudes, because everybody else is teaching facts. Students, interns, and residents come to us for training, but each has a different central nervous system and each gains satisfaction in a different way. The main thing for students to get out of medical school is a feeling of satisfaction with medicine. Through education and training, I attempt to recognize within individuals those areas [of 
their brains that] are structured in such a way that learning is easy and those areas where learning will occur only with a large input of energy. Because the medical profession is made up of many different kinds of people, our goal is to identify the best use of the individual and to find the limits imposed by his structure. The appreciation that behavior has a structural basis in the nervous system also is useful to the physician as he or she approaches patients. A doctor appreciates that habits are structurally determined and, once formed, they are modified with difficulty. I've always felt a teacher must be genuinely interested in others to teach." [1]

I'd also like to include the following quotes from the great Brazillian educator, Paolo Freire, that I think also gets at teaching, the teacher and the student. It is from his outstanding work The Pedagogy of the Oppressed [2]

'A careful analysis of the teacher-student relationship at any level, inside or outside the school, reveals its fundamentally narrative character. This relationship involves a narrating Subject (the teacher) and patient listening objects (the students). The contents, whether values or empirical dimensions of reality, tend in the process of being narrated to become lifeless and petrified. Education is suffering from narration sickness. The teacher talks about reality as if it were motionless, static, compartmentalized, and predictable. Or else he expounds on a topic completely alien to the existential experience of the students. His task is to "fill" the students with the contents of his narration - contents which are detached from reality, disconnected from the totality that engendered them and could give them significance. Words are emptied of their concreteness and become a hollow, alienated, and alienating verbosity.

Narration (with the teacher as narrator) leads the students to memorize mechanically the narrated account. Worse yet, it turns them into "containers," into "receptacles" to be "filled" by the teachers. The more completely she fills the receptacles, the better a teachers she is. The more meekly the receptacles permit themselves to be filled, the better students they are. Education thus becomes an act of depositing, in which the students are the depositories and the teacher is the depositor. Instead of communicating, the teacher issues communiqués and makes deposits which the students patiently receive, memorize, and repeat. This is the 'banking' concept of education, in which the scope of action allowed to the students extends only as far as receiving, filing, and storing the deposits. They do, it is true, have the opportunity to become collectors or cataloguers of the things they store. But in the last analysis, it is the people themselves who are filed away through the lack of creativity, transformation, and knowledge in this (at best) misguided system. For apart from inquiry, apart from the praxis, individuals cannot be truly human. Knowledge emerges only through invention and re-invention, through the restless, impatient continuing, hopeful inquiry human beings pursue in the world, with the world, and with each other.In the banking concept of education, knowledge is a gift bestowed by those who consider themselves knowledgeable upon those whom they consider to know nothing. Projecting an absolute ignorance onto others, a characteristic of the ideology of oppression, negates education and knowledge as processes of inquiry. The teacher presents himself to his students as their necessary opposite; by considering their ignorance absolute, he justifies his own existence. The students, alienated like the slave in the Hegelian dialectic, accept their ignorance as justifying the teachers existence - but unlike the slave, they never discover that they educate the teacher.

The raison d'etre of libertarian education, on the other hand, lies in its drive towards reconciliation. Education must begin with the solution of the teacher-student contradiction, by reconciling the poles of the contradiction so that both are simultaneously teachers and students.

This solution is not (nor can it be) found in the banking concept. On the contrary, banking education maintains and even stimulates the contradiction through the following attitudes and practices, which mirror oppressive society as a whole:

a. The teacher teaches and the students are taught;

$b$. the teacher knows everything and the students know nothing;

c. the teacher thinks and the students are thought about;

d. the teacher talks and the students listen - meekly;

e. the teacher disciplines and the students are disciplined;

f. the teacher chooses and enforces his choice, and the students comply;

g. the teacher acts and the students have the illusion of acting through the action of the teacher;

$h$. the teacher chooses the program content, and the students (who were not consulted) adapt to it;

$i$. the teacher confuses the authority of knowledge with his or her own professional authority, which she and he sets in opposition to the freedom of the students;

$j$. the teacher is the Subject of the learning process, while the pupils are mere objects.

It is not surprising that the banking concept of education regards men as adaptable, manageable beings. 
The more students work at storing the deposits entrusted to them, the less they develop the critical consciousness which would result from their intervention in the world as transformers of that world. The more completely they accept the passive role imposed on them, the more they tend simply to adapt to the world as it is and to the fragmented view of reality deposited in them." [2]

My message is that teaching IS helping our students to learn, not as empty vessels to be filled, but as co-participants on this journey to make this world a better place and for us as cancer educators, to rid this world of the suffering that comes with cancer.

\section{References}

1. Wallace, Andrew: Passing It On: The Stead Legacy, www.duke.medicine.org/repository

2. Freire P (2006) The Pedagogy of the Oppressed:Thirtieth Anniversery Edition. Continuum International Publishing Group, Inc, NY 